\title{
Pengaruh Perbedaan Metode Ekstraksi terhadap Aktivitas Antioksidan dan Kadar Fenolat Total dalam Ekstrak Daun Kelor (Moringa oleifera Lam.)
}

\section{The Effect of Different Extraction Methods on the Antioxidant Activity and Total Phenolic Content of Moringa (Moringa oleifera Lam.) Leaf Extract}

\author{
Verawati*, Tisa Mandala Sari, Hanne Savera \\ Sekolah Tinggi Farmasi Indonesia Perintis Padang \\ Jl. Adinegoro/Simp. Kalumpang Km 17 Lubuk Buaya Padang, 25173, Indonesia \\ *Corresponding author email: verawati81apt@gmail.com
}

Received 28-11-2019 Accepted 19-04-2020 Available online 01-07-2020

\begin{abstract}
ABSTRAK
Prosedur ekstraksi sangat mempengaruhi kualitas dan kuantitas komponen kimia yang dapat disari dari tanaman agar menghasilkan ekstrak yang kaya akan senyawa-senyawa bioaktif. Tujuan penelitian ini adalah untuk mengetahui pengaruh perbedaan metode ekstraksi terhadap aktivitas antioksidan dan kadar fenolat total dari ekstrak daun kelor (Moringa oleifera Lam.). Serbuk kering daun kelor diekstraksi dengan alkohol $70 \%$ dengan 4 metode, yaitu maserasi selama 2 jam dengan pengadukan $500 \mathrm{rpm}$ (E1), maserasi selama 2 jam dengan pengadukan $500 \mathrm{rpm}$ pada suhu $40{ }^{\circ} \mathrm{C}$ (E2), maserasi selama 1,5 jam dengan pengadukan $500 \mathrm{rpm}$ dilanjutkan ultrasonifikasi selama 30 menit pada frekuensi $40 \mathrm{kHz}$ (E3), dan maserasi selama 1,5 jam dengan pengadukan $500 \mathrm{rpm}$ dilanjutkan ultrasonifikasi selama 30 menit pada frekuensi $40 \mathrm{kHz}$ yang dilakukan pada suhu $40{ }^{\circ} \mathrm{C}$ (E4). Kadar fenolat total ditentukan dengan metode FolinCiocalteu, sedangkan aktivitas antioksidan dari masing-masing ekstrak diperiksa dengan metode perangkapan radikal DPPH. Hasil penelitian menunjukkan kadar fenolik total tertinggi terdapat pada E4 dan diikuti oleh E2, E3, dan E1 dengan kadar masing-masing 82,87; 82,13; E3 75,51, dan E1 73,39 mg/g GAE. Aktivitas antioksidan dinyatakan dengan nilai $\mathrm{IC}_{50}$, dimana aktivitas tertinggi diperoleh pada $\mathrm{E} 1$ dan diikuti oleh E3, E2, dan E4, masing-masing dengan nilai $\mathrm{IC}_{50}$ sebesar 61,$54 ; 67,37 ; 72,33$, dan E4 82,87 $\mu \mathrm{g} / \mathrm{mL}$. Dengan demikian, perbedaan metode ekstraksi ini mempengaruhi aktivitas antioksidan dan kadar fenolat total daun kelor.
\end{abstract}

Kata kunci: antioksidan, daun kelor, fenolat, Moringa oleifera Lam. 


\begin{abstract}
Extraction procedures greatly affect the quality and chemical components extracted from given plant materials. The purpose of this research was to evaluate the effect of different extraction methods on antioxidant activity and total phenolic content of Moringa (Moringa oleifera Lam.) leaf extract. The powdered moringa leaves were extracted with $70 \%$ alcohol by four methods, i.e., maceration for $2 \mathrm{~h}$ with $500 \mathrm{rpm}$ stirring (E1), maceration for $2 \mathrm{~h}$ with $500 \mathrm{rpm}$ stirring at $40^{\circ} \mathrm{C}$ (E2), maceration for $1.5 \mathrm{~h}$ with $500 \mathrm{rpm}$ stirring and continued with ultrasonication for $30 \mathrm{~min}$ at a frequency of 40 $\mathrm{kHz}(E 3)$, and maceration for $1.5 \mathrm{~h}$ with $500 \mathrm{rpm}$ stirring and followed by ultrasonication for $30 \mathrm{~min}$ at a frequency of $40 \mathrm{kHz}$ at $40{ }^{\circ} \mathrm{C}$ (E4). The total phenolic content was determined by the Folin-Ciocalteu method, while the antioxidant activity was evaluated by DPPH radical scavenging method. The results showed that the highest total phenolic content was shown by $E 4$ and subsequently followed by E2,E3, and E1 with the values of 82.87, 82.13, 75.51, and $73.39 \mathrm{mg} / \mathrm{g} \mathrm{GAE}$, respectively. The antioxidant activity was expressed in $I C_{50}$, in which the highest activity was shown by $E 1$ and followed by E3, E2, and $E 4$, with the respective $I C_{50}$ value of $61.54,67.37,72.33$, and $82.87 \mu \mathrm{g} / \mathrm{mL}$. It can be concluded that the different extraction methods affect the antioxidant activity and the total phenolic content of moringa leaves.
\end{abstract}

Key words: antioxidant, moringa leaves, Moringa oleifera Lam., phenolic compounds.

\section{Pendahuluan}

Daun kelor (Moringa oleifera Lam.) merupakan salah satu tumbuhan obat tradisional di Indonesia. Secara empiris daun kelor digunakan sebagai obat tradisional seperti untuk obat sakit kuning, rematik, nyeri dan pegal linu, sakit mata, sukar buang air kecil, cacingan, alergi, dan luka bernanah (Anwar et al., 2007). Daun kelor yang termasuk ke dalam suku Moringaceae, juga dapat digunakan untuk mencegah dan mengatasi keadaan malnutrisi. Hal ini karena tanaman kelor kaya akan nutrisi yang memiliki kandungan vitamin C (7 kali lipat dibandingkan jeruk), Vitamin A (10 kali dibandingkan wortel), Kalsium (17 kali dibandingkan susu), protein (9 kali dibandingkan yoghurt), potassium (15 kali dibandingkan pisang) dan besi ( 25 kali dibandingkan bayam) (Rockwood et al., 2013). Selain kandungan nutrisi tersebut, daun kelor juga mengandung sejumlah besar komponen fitokimia seperti kuersetin, asam klorogenat, karoten, kaempferol, vitamin $E$, vitamin $C$, polifenol, asam fenolat, flavonoid, alkaloid, golongan glikosida, komponen isotiosianat, tanin, dan saponin (Leone et al., 2015). Kandungan senyawa bioaktif yang tinggi ini menyebabkan daun kelor memiliki berbagai aktivitas farmakologi.

Sejumlah penelitian telah membuktikan aktivitas farmakologi dari daun kelor. Daun kelor telah diteliti memiliki aktivitas hipolipidemia, antioksidan, hepatoprotektif, antiinflamasi, antihiperglikemia, dan antikanker (Vergara-Jimenez et al., 
2017). Aktivitas tersebut berkaitan dengan penyakit-penyakit degeneratif yang disebabkan faktor usia dan keadaan stress oksidatif. Keadaan stress oksidatif timbul karena ketidakseimbangan jumlah radikal bebas dan antioksidan di dalam tubuh. Pada kondisi ini jumlah radikal bebas dalam tubuh lebih tinggi sehingga dapat menyebabkan kerusakan pada DNA, lipid, dan protein tubuh. Kerusakan ini dapat diatasi dengan meningkatkan jumlah asupan antioksidan (Jun et al., 2003).

Aktivitas farmakologi dari tanaman sangat berkaitan erat dengan kandungan kimia yang dimilikinya. Prosedur ekstraksi sangat mempengaruhi kualitas dan kuantitas komponen kimia yang dapat disari dari tanaman agar menghasilkan ekstrak yang kaya akan senyawa-senyawa bioaktif. Pemilihan metode ekstraksi yang tepat dapat meningkatkan jumlah senyawa aktif antioksidan tersebut. Senyawa fenolat merupakan golongan fitokimia yang memiliki aktivitas sebagai antioksidan (Wardi et al., 2019). Pada penelitian ini diperiksa pengaruh perbedaan metode ekstraksi terhadap aktivitas antioksidan dan kadar fenolat total dari ekstrak daun kelor. Aktivitas antioksidan ekstrak diuji secara in vitro menggunakan metode perangkapan radikal DPPH sedangkan kadar fenolat total ditentukan dengan metode Folin Ciocalteu.

\section{Metode Penelitian}

Alat dan Bahan

Alat-alat yang digunakan adalah seperangkat alat spektrofotometer UVVis (Shimadzu $\left.{ }^{\circ}\right)$, rotary evaporator (IKA ${ }^{\circ}$ ), hot plate dan magnetic stirrer, seperangkat alat ultrasonikasi, desikator, krus porselen, kaca arloji, glass beaker, gelas ukur, timbangan analitik, botol maserasi, kertas saring, corong, oven, tabung reaksi, erlenmeyer, vial, blender, aluminium foil.

Bahan-bahan yang digunakan adalah daun kelor (Moringa oleifera Lam.), akuades, etanol 70\%, asam galat, metanol p.a, natrium karbonat, reagen Folin-Ciocalteu, DPPH (1,1-difenil-2pikrilhidrazil).

\section{Jalannya Penelitian}

1. Ekstraksi daun kelor

Sampel daun kelor segar dibersihkan, dicuci kemudian dikeringanginkan. Setelah kering kemudian diserbuk. Serbuk daun ditimbang masing-masing 50 gram untuk setiap metode ekstraksi, dimana masing-masing diekstraksi dengan metode yang berbeda:

\section{Ekstraksi 1 (E1)}

Sebanyak 50 gram serbuk kering daun kelor dimasukkan dalam glass beaker, kemudian ditambahkan 500 $\mathrm{mL}$ etanol $70 \%$ sebanyak $500 \mathrm{~mL}$. Proses ekstraksi dilakukan selama 2 jam dengan kecepatan pengadukan 500 rpm menggunakan magnetic stirrer. Setelah itu dilakukan penyaringan, dan filtrat dipekatkan dengan rotary evaporator sehingga diperoleh ekstrak E1. 


\section{Ekstraksi 2 (E2)}

Sebanyak 50 gram serbuk kering dimasukkan ke dalam glass beaker kemudian ditambahkan pelarut etanol $70 \%$ sebanyak $500 \mathrm{~mL}$. Proses ekstraksi dilakukan di atas hot plate dengan suhu $40{ }^{\circ} \mathrm{C}$ selama 2 jam dengan kecepatan pengadukan 500 rpm. Setelah itu dilakukan penyaringan, dan filtrat dipekatkan dengan rotary evaporator sehingga diperoleh ekstrak E2.

\section{Ekstraksi 3 (E3)}

Sebanyak 50 gram serbuk kering daun kelor dimasukkan dalam glass beaker, kemudian ditambahkan 500 $\mathrm{mL}$ etanol $70 \%$. Proses ekstraksi dilakukan selama 1,5 jam dengan kecepatan pengadukan $500 \mathrm{rpm}$ kemudian dilanjutkan ultrasonikasi selama 30 menit pada frekuensi 40 kHz. Setelah itu dilakukan penyaringan, dan filtrat dipekatkan dengan rotary evaporator sehingga diperoleh ekstrak E3.

\section{Ekstraksi 4 (E4)}

Sebanyak 50 gram serbuk kering daun kelor dimasukkan dalam glass beaker, kemudian ditambahkan 500 $\mathrm{mL}$ etanol $70 \%$. Proses ekstraksi dilakukan di atas hot plate dengan suhu $40{ }^{\circ} \mathrm{C}$ selama 1,5 jam dengan kecepatan pengadukan 500 rpm kemudian dilanjutkan ultrasonikasi pada suhu $40{ }^{\circ} \mathrm{C}$ selama 30 menit pada frekuensi $40 \mathrm{kHz}$. Setelah itu dilakukan penyaringan, dan filtrat dipekatkan dengan rotary evaporator sehingga diperoleh ekstrak E4.
Setiap ekstrak kental dihitung persentase rendemennya terhadap berat awal serbuk daun, menggunakan rumus:

$\%$ rendemen $=\frac{\text { Bobot ekstrak }}{\text { Bobot serbuk daun }} \times 100 \%$

2. Penentuan aktivitas antioksidan (Molyneux, 2004)

Aktivitas antioksidan ekstrak daun kelor ditentukan dengan metode perangkapan radikal DPPH $\bullet$. Masing-masing ekstrak (E1, E2, E3, dan E4) dibuat larutan ujinya dalam metanol dengan deret konsentrasi 40, 60, 80, 100, dan $120 \mu \mathrm{g} / \mathrm{mL}$. Larutan dari tiap konsentrasi dipipet sebanyak $2 \mathrm{~mL}$ dan ditambahkan dengan $4 \mathrm{~mL}$ larutan $\mathrm{DPPH} \bullet 35 \mu \mathrm{g} / \mathrm{mL}$. Campuran larutan diukur serapannya pada $\Lambda 519$ $\mathrm{nm}$, setelah didiamkan selama 30 menit di tempat gelap. Persentase inhibisi ekstrak terhadap DPPH• dihitung dengan rumus:

$$
\% \text { inhibisi }=\left(1-A / A_{0}\right) \times 100 \%
$$

\section{Keterangan:}

$\mathrm{A}_{0}=$ absorban DPPH $\bullet$ tanpa ekstrak

$\mathrm{A}=$ absorban campuran DPPH $\bullet$ dan ekstrak

Nilai \% inhibisi diplot dengan nilai konsentrasi masing-masing ekstrak, kemudian dibuatkan kurva kalibrasinya. Berdasarkan persamaan regresi linier dari kurva kalibrasi, dapat dihitung nilai $I_{50}$ ekstrak, yaitu nilai konsentrasi yang menyebabkan inhibisi 50\% terhadap DPPH • . 
3. Penentuan kadar fenolat total (Khoddami et al., 2013)

Penentuan kadar fenolik total dilakukan dengan menggunakan reagen Folin-Ciocalteu. Larutan masing-masing ekstrak disiapkan dengan konsentrasi $1000 \mu \mathrm{g} / \mathrm{mL}$ dalam metanol. Larutan sampel dipipet $0,5 \mathrm{~mL}$ ditambahkan $5 \mathrm{~mL}$ pereaksi Folin-Ciocalteu (diencerkan 1:10 akuades), dan $4 \mathrm{~mL}$ larutan natrium karbonat $1 \mathrm{M}$ kemudian dikocok homogen. Campuran dibiarkan pada suhu kamar selama 15 menit kemudian diukur serapannya pada $\wedge 725 \mathrm{~nm}$. Standar baku yang digunakan adalah asam galat dengan deret konsentrasi larutannya 40,60, 80, 100, $120 \mu \mathrm{g} / \mathrm{mL}$. Kadar fenolat total diukur dengan menggunakan persamaan regresi dari kurva kalibrasi asam galat. Kadar fenolat dinyatakan dalam kesetaraan asam galat per gram bobot ekstrak (mg/g GAE).

\section{Hasil dan Pembahasan}

Hasil ekstraksi dari masing-
masing metode menunjukkan
persentase rendemen yang berbeda.

Tabel 1. Rendemen dan karakteristik ekstrak daun kelor

\begin{tabular}{rcll}
\hline Ekstrak & Rendemen (\%) & \multicolumn{2}{c}{ Organoleptis } \\
\hline E1 & 14,91 & Cairan kental, berwarna hijau \\
E2 & 16,70 & kecoklatan, tidak berwarna, dan rasa \\
E3 & 17,41 & agak pahit & \\
E4 & 17,59 & & \\
\hline
\end{tabular}

Penggunaan getaran ultrasonifikasi dapat meningkatkan proses ekstraksi karena getaran yang ada merusak/mengacaukan dinding sel sampel tanaman sehingga membantu pelepasan zat fitokimia dalam sel (Annegowda et al., 2012). Selain itu terjadi pemanasan lokal yang juga meningkatkan kelarutan zat pada pelarut pengekstraksi. Suhu pada saat ekstraksi juga berpengaruh, dimana pada suhu 40 ${ }^{\circ} \mathrm{C}$ lebih banyak jumlah zat yang terekstraksi dibandingkan ekstraksi pada suhu kamar. Pemanasan juga lebih membuka pori-pori membran sel dan membantu peningkatan kelarutan zat. Di lain pihak, adanya pemanasan ini bisa menyebabkan beberapa senyawa volatil hilang selama proses.

Pemeriksaan aktivitas antioksidan dari daun kelor menggunakan metode perangkapan radikal DPPH (1,2-difenil-2-pikrilhidrazil). Metoda DPPH dipilih karena merupakan metoda sederhana, mudah, peka, dan hanya memerlukan sedikit sampel dengan waktu pengerjaan yang relatif lebih singkat. Radikal bebas DPPH akan dirangkap/dikopling dengan proton yang didonorkan oleh senyawa antioksidan 
dari ekstrak daun kelor. Perubahan molekul DPPH menjadi molekul netral/tidak radikal dapat diamati melalui perubahan warna larutan reaksi dari ungu violet menjadi kuning atau bahkan tidak berwarna. Hasil pemeriksaan aktivitas antioksidan daun kelor dapat dilihat pada Tabel 2.

Kadar fenolat total ekstrak daun kelor ditentukan dengan metode FolinCiocalteu. Metoda ini merupakan metoda yang paling umum digunakan untuk penentuan kandungan fenolat total dalam tumbuhan dengan pertimbangan bahwa dengan teknik ini pengerjaannya lebih sederhana, dan reagen Folin-Ciocalteu dapat bereaksi dengan senyawa fenolat membentuk larutan yang dapat diukur absorbansinya. Reagen Folin-Ciocalteu berwarna kuning dan akan membentuk komplek berwarna biru bila bereaksi dengan senyawa fenolat dalam suasana basa dengan penambahan natrium karbonat. Asam galat digunakan sebagai baku standar pada metode ini sehingga kadar fenolat yang diperoleh dihitung sebagai kesetaraan dengan bobot asam galat. Hasil penentuan kadar fenolat total diperlihatkan pada Tabel 2.

Tabel 2. Aktivitas antioksidan dan kadar fenolat total ekstrak daun kelor

\begin{tabular}{ccc}
\hline Ekstrak & $\mathbf{I C}_{\mathbf{5 0}}(\boldsymbol{\mu \mathrm { g }} / \mathbf{m L})$ & Kadar Fenolat $(\mathbf{m g} / \mathbf{g}$ GAE) \\
\hline E1 & 61,54 & 73,39 \\
E2 & 72,33 & 82,13 \\
E3 & 67,37 & 75,51 \\
E4 & 85,71 & 82,87 \\
\hline
\end{tabular}

Aktivitas antioksidan dari ekstrak daun kelor dinyatakan dengan $I_{50}$. Semakin rendah nilai $I_{50}$ maka aktivitas antioksidan sampel semakin tinggi. Urutan aktivitas antioksidan ekstrak daun kelor yang diperoleh dari beberapa metode ekstraksi menunjukkan nilai yang berbeda-beda, dimana urutan aktivitas antioksidan mulai dari yang tertinggi adalah E1 $>$ E3>E2 $>$ E4. Secara keseluruhan kekuatan aktivitas antioksidan daun kelor yang berkisar pada rentang nilai $\mathrm{IC}_{50} 61,54-85,71 \mu \mathrm{g} / \mathrm{mL}$, tergolong pada antioksidan kuat. Berdasarkan nilai $\mathrm{IC}_{50}$,

kekuatan antioksidan diklasifikasikan sebagai berikut yaitu: sangat kuat $(<50$ $\mu \mathrm{g} / \mathrm{mL})$, kuat $(50-100 \mu \mathrm{g} / \mathrm{mL})$, sedang $(101-150 \mu \mathrm{g} / \mathrm{mL})$, dan lemah (>150 $\mu \mathrm{g} / \mathrm{mL}$ ) (Najafabadi et al., 2019). Aktivitas antioksidan ini menurun pada metode ekstraksi yang menggunakan pemanasan, hal ini mungkin disebabkan karena terdapat senyawa-senyawa aktif di dalam daun kelor yang bersifat termolabil.

Berdasarkan hasil tersebut,
dapat diduga bahwa aktivitas
antioksidan tidak hanya diberikan oleh
senyawa golongan fenolat saja tetapi


dapat pula diberikan oleh senyawasenyawa golongan lain seperti steroid, dan klorofil dari daun kelor tersebut. Selain itu tidak semua senyawa golongan fenolat memberikan aktivitas antioksidan karena dipengaruhi oleh struktur kimia dan gugus hidroksilnya.

Kadar fenolat total diperoleh dengan cara memasukkan nilai absorban larutan ekstrak yang telah direaksikan dengan reagen Folin-Ciocalteu, ke dalam persamaan regresi dari kurva kalibrasi larutan standar asam galat. Persamaan regresi dari standar baku adalah $y=0,042+0,00424 x$. Koefisien korelasi $(r)$ persamaan regresi yaitu 0,9991. Nilai $r$ menunjukkan linearitas kurva dan korelasi yang tinggi antara nilai absorban dan konsentrasi. Batas deteksi sebesar $1,89 \mu \mathrm{g} / \mathrm{mL}$, dan batas kuantisasi 6,33 $\mu \mathrm{g} / \mathrm{mL}$. Kadar fenolat dari masing-masing ekstrak paling tinggi diperoleh pada metode $\mathrm{E} 4(82,87 \mathrm{mg} / \mathrm{g}$ GAE) diikuti E2 $(82,13 \mathrm{mg} / \mathrm{g} \mathrm{GAE})$, E3 75,51 (mg/g GAE), dan $\mathrm{E} 1(73,39 \mathrm{mg} / \mathrm{g}$ GAE).

Berdasarkan hasil penelitian ini diperoleh kadar ekstrak tertinggi terdapat pada metode ekstraksi ke-4 (E4) dan kadar fenolat tertinggi juga terdapat pada E4. Hal ini kemungkinan disebabkan pada metode ini dilakukan pemanasan pada suhu $40{ }^{\circ} \mathrm{C}$ dan metoda ultrasonikasi yang dapat lebih mengoptimalkan proses ekstraksi sehingga meningkatkan rendemen dan kadar fenolatnya. Aktivitas antioksidan yang kuat terdapat pada ekstrak hasil metode E1 dimana metode ekstraksinya dilakukan tanpa pemanasan sehingga tidak merusak senyawa antioksidan dan tidak merusak komponen kimia yang tidak tahan terhadap pemanasan.

\section{Simpulan}

Perbedaan metode ekstraksi mempengaruhi perolehan kadar fenolat total dan aktivitas antioksidan ekstrak daun kelor. Metode E4 menghasilkan ekstrak yang memiliki kadar fenolat total tertinggi sedangkan metode E1 menghasilkan ekstrak yang memiliki aktivitas antioksidan terbaik.

\section{Daftar Pustaka}

Annegowda, H.V., Bhat, R., Min-Tze, L., Karim, A.A., Mansor, S.M. 2012. Influence of sonication treatments and extraction solvents on the phenolics and antioxidants in star fruits. Journal of Food Science and Technology, 49(4):510-514.

Anwar, F., Latif, S., Ashraf, M., Gilani, A.H. 2007. Moringa oleifera: a food plant with multiple medicinal uses. Phytotherapy Research, 21(1):17-25.

Jun, M., Fu, H.Y., Hong, J., Wan, X., Yang, C.S., Ho, C.T. 2003. Comparison of antioxidant activities of isoflavones from kudzu root (Pueraria lobata Ohwi). Journal of Food Science, 68(6):21172122.

Khoddami, A., Wilkes, M.A., Roberts, T.H. 2013. Techniques for analysis of plant phenolic compounds. Molecules, 18(2): 2328-2375.

Leone, A., Spada, A., Battezzati, A., Schiraldi, A., Aristil, J., Bertoli, S. 
2015. Cultivation, genetic, ethnopharmacology,

phytochemistry and

pharmacology of Moringa

oleifera leaves: an overview.

International Journal of

Molecular Sciences,

16(6):12791-12835.

Molyneux, P. 2004. The use of the stable free radical diphenylpicrylhydrazyl (DPPH) for estimating antioxidant activity. Songklanakarin Journal of Science and Technology, 26(2):211-219.

Najafabadi, S.F., Safaeian, L., Zolfaghari, B. 2019. In vitro antioxidant effects of different extracts obtained from the leaves and seeds of Allium ampeloprasum subsp. persicum. Journal of Herbmed Pharmacology, 8(3): 10-15.

Rockwood, J.L., Anderson, B.G.,
Casamatta, D.A. 2013. Potential uses of Moringa oleifera and an examination of antibiotic efficacy conferred by M. oleifera seed and leaf extracts using crude extraction techniques available to underserved indigenous populations. International Journal of Phytotherapy Research, 3(2):6171.

Vergara-Jimenez, M., Almatrafi, M.M., Fernandez, M.L. 2017. Bioactive components in Moringa oleifera leaves protect against chronic disease. Antioxidants, 6(4):1-13.

Wardi, E.S., Zulkarni, R., Nurdianti, D. 2019. Penentuan kadar fenolat total dan aktivitas antioksidan dari ekstrak daun dadap merah (Erythrina fusca Lour) secara spektrofotometri UV-Vis. AsSyifaa Jurnal Farmasi, 11(01):916. 